\title{
THE OPINIONS OF TEACHERS AND STUDENTS IN THE SCIENCE AND ART CENTER REGARDING THE CONCEPT OF SPECIAL TALENTED
}

\author{
Cavide Demirci ${ }^{11}$, \\ Sedef Çelik ${ }^{2}$, \\ Sündüz Özer ${ }^{3}$ \\ ${ }^{1}$ Faculty of Education, \\ Eskişehir Osmangazi University, \\ Eskişehir, Turkey \\ orcid.org/0000-0003-4789-4286 \\ 2Institute of Educational Sciences, \\ Eskişehir Osmangazi University, \\ Eskişehir, Turkey \\ orcid.org/0000-0003-4793-3070 \\ ${ }^{3}$ Institute of Educational Sciences, \\ Eskişehir Osmangazi University, \\ Eskişehir, Turkey \\ orcid.org/0000-0001-8053-3170
}

\begin{abstract}
:
Considering the potential of special talented students, the importance of training them is increasing day by day. The perspectives of special talented students and their teachers regarding the concept of special talented are also effective in revealing students' potential. The aim of this study is to determine the opinions of the teachers and students in the Science and Art Center about the concept of special talented. The study was carried out with 20 teachers and 55 students in Science and Art Centers in Turkey in the 2019-2020 academic year. Case study, one of the qualitative research designs, was used. Participants were determined using accessible case sampling. A semi-structured interview form prepared by the researchers was used as a data collection tool. Descriptive analysis was used to analyze the data obtained as a result of the interviews. It has been tried to reflect the positive and negative aspects of special talented students from the perspective of teachers and students. As a result of this study, it has been determined that teachers and students in the Science and Art Center perceive the concept of special talented students as individuals who offer creative solutions to problems and who have a quick grasp. In addition, both students and teachers think that receiving education at Science and Art Centers makes positive contributions to students. Finally, different types of suggestions
\end{abstract}

\footnotetext{
${ }^{1}$ Correspondence: email demircicav@gmail.com, sdphcelik@gmail.com, so069212@gmail.com
} 
are made in order to increase the positive sides and eliminate the negative sides of special talented students.

Keywords: special talented student, teacher, science and art center

\section{Introduction}

As stated in the constitutional and universal law texts, education is the fundamental right of every individual, and it is also their right to be educated according to their abilities and capacities. Students with different levels of development compared to their peers are subjected to special education. Special education is the application of education as the basic right for students with different levels of development. When the literature is examined, it is seen that these students whose development level is advanced compared to their peers are named in different ways as "gifted" or "talented". However, the Ministry of National Education names these students, whose level of development is advanced compared to their peers, as special talented in the legislative content published. The Ministry of National Education refers special talented individual as individuals who learn faster than their peers, who are prominent in creativity, art and leadership capacity, have special academic skills, can understand abstract ideas, like to act independently in their areas of interest and show high performance. Considering the common views in the definitions made for special talented students in the literature; it can be summarized as being able to think quickly and critically, being creative and original, having high level skills in problem solving, picturing and comprehending events in the mind. Special talented students differ from their peers due to their characteristics. These differences that they have are a unique opportunity for their wealth and the society where they live. The basic principles of education are to provide education to everyone equally, according to need, having continuity, providing equal opportunity, secular, democratic, scientific, in accordance with Atatürk's principles and reforms. When we look at all the principles that exist in education, the basic point is that each individual gets education according to his / her developmental characteristics. The power of the capacity of the special talented students necessitates their education. In addition, studies for the education and training of special talented individuals are not a process that only concerns special talented students. They also provide an indirect impact on the lives of the people they live with (cited. Kayışdağ and Melekoğlu, 2018, p.3). The Ministry of National Education has been conducting studies for special talented individuals since the 1990s. Science and Art Centers are opened by the Ministry of National Education in order to provide the richness of the education life of special talented students in Turkey. Science and Art Centers create educational environments for special talented students and contribute to their education by creating their own learning environments. Educational activities are organized in Science and Art Centers according to individual education plans prepared for special talented students. The Science and Art Center organizes an academic life where special talented students are at the center and educational environments that will enable them 
to engage in scientific activities. (Akbüber and others., 2019, p.24). Considering the literature, Bakioğlu and Levent (2013) showed results in terms of enriching the educational content of Science and Art Centers and improving the educational environments, and also enabling gifted students to benefit more from these environments by increasing their number throughout the country. The Science and Art Centers should increase their qualifications by considering the potential they carry. The existence of studies aimed at revealing the potential within special talented students becomes mandatory.

As a matter of fact, teachers are the most important guides who provide support by following the development of special talented students. In the research of McCarty, Abbott-Shim, and Lambert (2001), it was observed that teachers reflected their adopted philosophies, perceptions and attitudes on the teaching methods and in-class practices they used. Teachers have an important place in educating special talented students according to their potential. They are the managers of the training program to be offered to special talented students. It is possible for teachers to be able to do the management job without any problems if they get to know the positive and negative characteristics of these students they have in the best way. In studies on teachers who provide educational support to special talented students and their views on special talented students, Yumuş and Toptaş (2011) state that teachers conduct academic studies based on the developmental characteristics of special talented students. Sak (2010) states that teachers can only guide them in the best way if they have high level knowledge about special talented students. According to this, teachers should look at special talented students from wide-angle windows, not equate them with their normally developing peers, respect their differences and take their spiritual development into account. Teachers who will appeal to special talented students should not only have the qualifications to enable them to graduate, but also have sufficient knowledge and experiences to provide academic and psychological progress to special talented students. (cited. Akbüber and others., 2019, p.26). Since the perception level of special talented students is different from individuals with normal development, they expect the training programs applied to them to be different. The difference of teachers and educational environments determined for them is extremely important. The characteristics of special talented students who share the same educational environments with their normally developing peers should be taken into consideration and the arrangements to be made should be at a level to support their development. The negative situations experienced in educational environments are related to the different characteristics of special talented students. (Seeman, 2010, p.29). Training programs to be prepared to minimize negativities are important and facilitate the operation. These training programs that teachers will prepare are about how well they know the student. The fact that the information they have about the positive and negative aspects of gifted students are systematized on paper and the arrangements made for individual differences are clear, makes education enjoyable.

A lot of academic studies are encountered in the literature review of special talented students. There are numerous studies such as the opinions of teachers working 
at Science and Art Center (Levent, 2012; Ayaydın and Ün, 2018); teachers' views on training programs for gifted students (Kazu and Şenol, 2012; Tortop and Ersoy, 2015; Ferelli, 2019; Kayışdă̆ and Melekoğlu, 2018); special talented students (Koçak and İçmenoğlu, 2016; Dilekli and Tezci, 2019); about the gifted students who are compared with their peers (Özarslan, 2019) and the opinions of candidate teachers about special talented students (Erdoğan and Güçyeter, 2019). In this context, the aim of this study is to determine the opinions of the teachers and students in the Science and Art Center. Therefore, this study is so important in terms of analyzing and revealing the opinions of teachers and students on the same subject. For this purpose, the research aims to find answers to the following sub-problems:

1) What are the positive aspects of special talented students?

2) What are the negative aspects of special talented students?

3) What are the suggestions for special talented students?

\section{Method}

This research was carried out according to the case study design, one of the qualitative research approaches. The case study focuses on facts that we are aware of but do not have a comprehensive and detailed understanding. (Yıldırım and Şimşek, 2013, p.78) In this context, the research will contribute to the determination of the views that teachers and students are aware of the positive and negative aspects of special talented students but do not have a detailed understanding of these issues.

\subsection{Study Group}

Participants of this study are 20 teachers and 55 students in Science and Art Centers in Turkey in the 2019-2020 academic year. They were chosen from among the volunteer teachers and the students in these institutions. Easily accessible sampling was used in determining the participants. In the easily accessible situation sampling, the researcher chooses the situation that is close to her/him and that she/he will not have difficulty in accessing. Thus, it accelerates the research and makes it useful. (Yıldırım and Şimşek, 2018 , p.123). Teachers who participated in the study were given codes such as K1, K2, K3 ... and students as $\mathrm{T} 1, \mathrm{~T} 2, \mathrm{~T} 3 \ldots$.

The demographic information of the teachers is given in Table 1.1 and the demographic characteristics of the students are given in Table 1.2.

Table 1.1: The Personal Information of Teachers

\begin{tabular}{|l|l|c|c|}
\hline & & $\mathbf{n}$ & $\mathbf{\%}$ \\
\hline \multirow{3}{*}{ Gender } & Women & 10 & 50 \\
\cline { 2 - 4 } & Men & 10 & 50 \\
\hline \multirow{3}{*}{ Educational Level } & Bachelor Degree & 9 & 45 \\
\cline { 2 - 4 } & Master's degree & 10 & 50 \\
\cline { 2 - 4 } & Doctorate & 1 & 5 \\
\hline Branch & Turkish & 1 & 5 \\
\hline
\end{tabular}


ART CENTER REGARDING THE CONCEPT OF SPECIAL TALENTED

\begin{tabular}{|l|l|c|c|}
\hline \hline \multirow{5}{*}{} & Mathematics & 1 & 5 \\
\cline { 2 - 4 } & Social Studies & 1 & 5 \\
\cline { 2 - 4 } & Form Teacher & 2 & 10 \\
\cline { 2 - 4 } & Psychological Counselling and Guidance & 2 & 10 \\
\cline { 2 - 4 } & Biology & 1 & 5 \\
\cline { 2 - 4 } & Information Technology & 1 & 5 \\
\cline { 2 - 4 } & Physics & 1 & 5 \\
\cline { 2 - 4 } & Chemistry & 1 & 5 \\
\cline { 2 - 4 } & English & 1 & 5 \\
\cline { 2 - 4 } & Art Lessons & 6 & 30 \\
\hline Professional Seniority & $0-5$ years & 0 & 0 \\
\cline { 2 - 4 } & $6-10$ years & 3 & 35 \\
\cline { 2 - 4 } & $11-15$ years & 5 & 25 \\
\cline { 2 - 4 } & $16-20$ years & $\mathbf{2 0}$ & $\mathbf{1 0 0}$ \\
\cline { 2 - 4 } & 21 years and more & & \\
\hline Total & & 5 & 25 \\
\hline
\end{tabular}

The study group of the research consists of twenty teachers. Ten of these teachers are female and ten are male. Ten of the teachers have a master's degree, nine have a bachelor's degree and one has a doctorate education. The branches of the teachers participating in the study consist of Turkish, Mathematics, Social Studies, Form Teacher, Psychological Counselling and Guidance, Biology, Information Technologies, Physics, Chemistry, English and Art courses. Considering the years that the teachers have spent in the profession; it is seen that seven teachers have been in their professional life for 6-10 years, three teachers for 11-15 years, five teachers for 16-20 years, and five teachers for 21 years or more.

Table 1.2: The Demography of Students

\begin{tabular}{|l|l|c|c|}
\hline \multirow{3}{*}{ Gender } & & $\mathbf{n}$ & $\mathbf{\%}$ \\
& Girl & 23 & 41,81 \\
\cline { 2 - 4 } & Boy & 32 & 58,18 \\
\hline \multirow{4}{*}{ Grade } & $2-3-4$ & 43 & 78,18 \\
\cline { 2 - 4 } & $5-6-7-8$ & 10 & 18,18 \\
\cline { 2 - 4 } & $9-10-11-12$ & 2 & 3,63 \\
\hline Total & & $\mathbf{5 5}$ & $\mathbf{1 0 0}$ \\
\hline
\end{tabular}

When the demographic information of the students is examined, it is seen that 23 students are female and 32 students are male. Looking at the grade levels, it is seen that there are 43 students at the 2-3-4 grade level, 10 students at the 5-6-7-8 grade level and 2 students at the 9-10-11-12 grade level.

\subsection{Data Collection Tools}

In this study, a semi-structured interview form prepared by the researchers was used. A literature review was conducted for the questions in the interview form, and the questions related to the purpose of the study were determined and a semi-structured 
interview form was created. Expert opinion was taken for the content validity of the data collection tool. In line with the expert opinion, the questions to be asked to the teacher were also made applicable to the students and applied to both teachers and students.

\subsection{Process}

The students and teachers selected as the study group were asked the following questions in the semi-structured interview form.

1. What are your views on the positive aspects of special talented students?

1.1 What qualities come to your mind when you think of a special talented student?

1.2 How do you think the training program for special talented students contributed to their development?

2. What are your views on the negative aspects of special talented students?

2.1 If there are disadvantages of working with special talented students, what are they?

2.2 What are the negative behaviours that special talented students exhibit in the classroom?

3. What are your suggestions for special talented students?

3.1 What are your suggestions for revealing more positive aspects of special talented students?

3.2 What are your suggestions for eliminating the negative aspects of special talented students?

A face-to-face meeting was held with the teachers and students. In order to ensure internal validity, statements taken from teachers and students were included in the study.

\subsection{Data Analysis}

The data obtained from the semi-structured interview form were presented according to the themes created based on the interview questions. The data obtained from the research were described systematically and clearly. In the next stage, these descriptions were interpreted and the results of the study were reached. In the study, direct quotations were used to reflect the opinions of the participants.

\section{Results}

In the study, the findings were given in an order appropriate to the interview questions. In the descriptions, the views of teachers and students are given by comparing them with each other.

\subsection{Opinions on the Positive Aspects of Special Talented Students}

The opinions of teachers and students working in the Science and Art Center about the positive aspects of special talented students, what concepts come to mind of teachers and 
students when it comes to special talented students, and whether the programs applied to special talented students contribute to their development are discussed.

\subsubsection{The Thoughts of Teachers and Students in the Science and Art Center about the Concept of Special Talented Student}

In the study, the thoughts associated with the concept of special talented students were obtained by asking the question "What qualities come to your mind when you think about special talented students?" The data obtained within the scope of this question are depicted in Table 2.

Table 2: Opinions about the Concept of Special Talented Student

\begin{tabular}{|l|l|c|c|l|c|c|}
\hline Items & \multicolumn{1}{|c|}{ Teachers } & $\mathbf{n}$ & $\mathbf{9}$ & \multicolumn{1}{|c|}{ Students } \\
\hline a) Grasping quickly. & $\begin{array}{l}\text { K1, K2, K3, } \\
\text { K8, K12, K13, } \\
\text { K19 }\end{array}$ & 7 & 35 & $\begin{array}{l}\text { Ö1, Ö8, Ö11, Ö20, Ö21, Ö23, } \\
\text { Ö26, Ö38, Ö44, Ö45, Ö49, } \\
\text { Ö50, Ö51, Ö52, Ö53 }\end{array}$ & 15 & 27,27 \\
\hline b) Presenting original designs. & K7, K10 & 2 & 10 & Ö9, Ö12, Ö16, Ö29, Ö30, Ö40 & 6 & 10,90 \\
\hline c) Having different personality. & K4, K15, K17 & 3 & 15 & Ö4, Ö10, Ö37, Ö39, Ö46, Ö55 & 6 & 10,90 \\
\hline d) Having broad perspective. & K11, K16, K18 & 3 & 15 & $\begin{array}{l}\text { Ö6, Ö14, Ö17, Ö22, Ö27, } \\
\text { Ö28, Ö34, Ö35, Ö36, Ö43 }\end{array}$ & 10 & 18,18 \\
\hline $\begin{array}{l}\text { e) Offering creative solutions to } \\
\text { problems. }\end{array}$ & $\begin{array}{l}\text { K5, K6, K9, } \\
\text { K20 }\end{array}$ & 4 & 20 & $\begin{array}{l}\text { Ö2, Ö5, Ö7, Ö13, Ö15, Ö18, } \\
\text { Ö19, Ö24, Ö25, Ö31, Ö32, } \\
\text { Ö33, Ö41, Ö42, Ö47, Ö48, } \\
\text { Ö54 }\end{array}$ & 17 & 30,90 \\
\hline $\begin{array}{l}\text { f) Other } \\
\text { * An individual who is different } \\
\text { from his / her peers and has } \\
\text { advanced knowledge and skills. }\end{array}$ & K14 & 1 & 5 & $\begin{array}{l}\text { *Very talented individual } \\
\text { Ö3 }\end{array}$ & 1 & 1,81 \\
\hline Total & & $\mathbf{2 0}$ & $\mathbf{1 0 0}$ & & $\mathbf{5 5}$ & $\mathbf{1 0 0}$ \\
\hline
\end{tabular}

When Table 2 is examined, it is observed that there is a variety of answers regarding the definition of special talented students. It is seen that answers are given in the form of highly talented individuals who are quick to grasp, present original designs, have different personalities, offer creative solutions to problems with a wide perspective, are different from their peers and have advanced knowledge and skills regarding the definition of special talented students. In addition, while $35 \%$ of the teachers define them as individuals who can grasp quickly, 30.9\% of the students define them as individuals who offer creative solutions to problems. It is seen that most of the teachers' and students' views are not very different from each other. To give an example; K7 and T9 mentioned about the concept as "Presenting original designs", K15 and T37 "Having different personalities", K6 and T43 "Having broad perspectives", K5 and T33 "Creative solutions to problems. However, few of them had different opinions about the concept. For instance, K14 described them as "Individuals with advanced knowledge and skills" and Ö3 described as "Very talented individual". 


\subsubsection{Evaluation of the Education Program for Special Talented Students by Science and Art Center Teachers and Students}

In the study, in order to evaluate the contribution of the education program applied to special talented students, "Does the education program for special talented students contribute to their development? And if you think it contributes, how does it contribute? " questions were directed to both teachers and students. The data obtained within the scope of this question are depicted in Table 3.

Table 3: Views on the Contribution of the Education Program For Special Talented Students to Their Development

\begin{tabular}{|c|c|c|c|c|c|c|c|}
\hline Items & Teachers & $\mathbf{n}$ & $\%$ & \multicolumn{2}{|l|}{ Students } & $\mathbf{n}$ & $\%$ \\
\hline $\begin{array}{l}\text { a) Allows to look } \\
\text { from different } \\
\text { angles. }\end{array}$ & $\begin{array}{l}\mathrm{K} 1, \mathrm{~K} 3, \mathrm{~K} 6, \\
\mathrm{~K} 8, \mathrm{~K} 9, \mathrm{~K} 12, \\
\mathrm{~K} 15, \mathrm{~K} 16 \\
\mathrm{~K} 18\end{array}$ & 9 & 45 & \multicolumn{2}{|l|}{$\begin{array}{l}\text { Ö2, Ö7, Ö19, Ö21, Ö28, Ö30, Ö34, Ö37, } \\
\text { Ö39, Ö40 } \\
\text { Ö46, Ö49, Ö52 }\end{array}$} & 13 & 23,63 \\
\hline $\begin{array}{l}\text { b) Encourages them } \\
\text { to research different } \\
\text { topics. }\end{array}$ & K19 & 1 & 5 & \multicolumn{2}{|l|}{ Ö4, Ö13, Ö38, Ö47, Ö51 } & 5 & 9,09 \\
\hline $\begin{array}{l}\text { c) Helps them } \\
\text { develop original } \\
\text { products. }\end{array}$ & K7, K11, K14 & 3 & 15 & \multicolumn{2}{|l|}{ Ö9, Ö27, Ö35 } & 3 & 5,45 \\
\hline $\begin{array}{l}\text { d) Increases the } \\
\text { knowledge of } \\
\text { students. }\end{array}$ & $\begin{array}{l}\text { K10, K13, K5, } \\
\text { K17 }\end{array}$ & 4 & 20 & \multicolumn{2}{|l|}{$\begin{array}{l}\text { Ö11, Ö3, Ö5, Ö6, Ö8, Ö10 } \\
\text { Ö11, Ö14, Ö15, Ö16, Ö17, } \\
\text { Ö18, Ö20, Ö22, Ö23, Ö24, } \\
\text { Ö26, Ö29, Ö31, Ö32, Ö33, } \\
\text { Ö36, Ö42, Ö43, Ö44, Ö45, } \\
\text { Ö48, Ö50, Ö53, Ö54, Ö55 }\end{array}$} & 31 & 56,36 \\
\hline $\begin{array}{l}\text { e) Improves } \\
\text { interpretation skills. }\end{array}$ & K20 & 1 & 5 & & & & \\
\hline $\begin{array}{l}\text { f) Other. } \\
* \text { Allows me to } \\
\text { spend my time } \\
\text { learning different } \\
\text { subjects. } \\
\text { * It enables students } \\
\text { to realize and } \\
\text { develop their } \\
\text { talents. }\end{array}$ & K2 & 2 & 10 & $\begin{array}{l}\text { f) Other } \\
\text { *Develop different designs } \\
\text { * It enables me to learn everything } \\
\text { and be successful, to spend time } \\
\text { learning different subjects, to } \\
\text { realize students' abilities, and to } \\
\text { improve their thinking skills. } \\
\text { * It broadens my imagination. }\end{array}$ & $\begin{array}{l}\text { Ö12 } \\
\text { Ö25 } \\
\text { Ö41 }\end{array}$ & 3 & 5,45 \\
\hline Total & & 20 & 100 & & & 55 & 100 \\
\hline
\end{tabular}

When the findings in Table 3 are evaluated, all of the teachers and students in the Science and Art Center think that the educational programs implemented to special talented students contribute to the development of them. Teachers state that the education program applied provides a different perspective especial for special talented students. They express that this programme facilitates the students to increase their knowledge and make original studies, and at this point they become aware of their abilities. Students, on the other hand, state that the education program increases the knowledge. They 
mention about the fact that it provides a different perspective and the improving effect of research skills. When looking at the table, it is seen that $45 \%$ of the teachers have stated that these educational programs have enabled student to look from different angles, while $56.6 \%$ of the students have said that they have increased the knowledge of the students. Teachers and students agree that the education program gives a different perspective, increases their curiosity to new subjects, provides knowledge, and enables to produce unique products. However, while the teachers stated that it increased the students' interpretation skills, the students not express their thoughts in this direction. Apart from the common answers given, some of the teachers said that the contribution of the curriculum helped them to deal with different subjects in using their time and to discover their abilities; some of the students stated that the program was applied which develops their thinking skills, helps to create different designs and develops their imagination. It is seen that the answers from teachers as K2 "it provides to spend time by learning different subjects" , K4 "it enables students to realize and develop their talents"; from students as Ö12 "it enables to develop different designs", Ö25 "it allows to learn everything and spend time learning different subjects", Ö41 "it contributes to the development of imagination".

\subsection{Opinions on Negative Sides of Special Talented Students}

Teachers and students working at the Science and Art Center were asked what their opinions were about the negative aspects of special talented students. Teachers were asked to state their "opinions on the negative aspects of working with special talented students". Students were asked to state their "opinions on the negative aspects of studying with their special talented fellows". In this context, the findings are summarized in Table 4.

Table 4: Opinions on the Negative Aspects of Being

Together with Special Talented Students

\begin{tabular}{|c|c|c|c|c|c|c|}
\hline Items & Teachers & $\mathrm{n}$ & $\%$ & Students & $\mathbf{n}$ & $\%$ \\
\hline $\begin{array}{l}\text { a) I can't keep up with their } \\
\text { speed because of their constant } \\
\text { asking questions. } \\
\text { I can't stand the smug attitude } \\
\text { of my friends. }\end{array}$ & & & & $\begin{array}{l}\text { Ö11, Ö18, Ö22, Ö23, } \\
\text { Ö31, Ö46, Ö55 }\end{array}$ & 7 & 12,72 \\
\hline $\begin{array}{l}\text { b) It makes me feel inadequate } \\
\text { when I can't keep up with their } \\
\text { pace. }\end{array}$ & & & & $\begin{array}{l}\text { Ö5, Ö19, Ö20, Ö32, } \\
\text { Ö36, Ö39, Ö41 }\end{array}$ & 7 & 12,72 \\
\hline $\begin{array}{l}\text { c) I always have to come up } \\
\text { with something new. }\end{array}$ & K7, K8, K12 & 3 & 15 & Ö53 & 1 & 1,81 \\
\hline d) It is wearing out. & $\begin{array}{l}\text { K2, K5, K6, K11, } \\
\text { K13, K14, K16, } \\
\text { K17, K18, K19 }\end{array}$ & 10 & 50 & Ö8, Ö9, Ö16, Ö17, Ö42 & 5 & 9,09 \\
\hline $\begin{array}{l}\text { e) I feel myself competing with } \\
\text { my friends. }\end{array}$ & & & & $\begin{array}{l}\text { Ö10, Ö13, Ö15, Ö27, } \\
\text { Ö28, Ö33, Ö49, Ö51, } \\
\text { Ö52 }\end{array}$ & 9 & 16,36 \\
\hline
\end{tabular}




\begin{tabular}{|c|c|c|c|c|c|c|}
\hline $\begin{array}{l}\text { f) My friends' know-it-all } \\
\text { attitudes prevent me from } \\
\text { learning. }\end{array}$ & & & & Ö7, Ö21, Ö40, Ö50, Ö54 & 5 & 9,09 \\
\hline g) None. & & & & $\begin{array}{l}\text { Ö1, Ö2, Ö4, Ö6, Ö12, } \\
\text { Ö14, Ö24, Ö25, Ö26, } \\
\text { Ö29, Ö34, Ö35, Ö37, } \\
\text { Ö38, Ö43, Ö44, Ö45, } \\
\text { Ö47, Ö48 }\end{array}$ & 19 & 34,54 \\
\hline $\begin{array}{l}\text { h) Other } \\
\text { * Nothing } \\
\text { * I have not experienced it, but } \\
\text { parents make the process } \\
\text { difficult for their children with } \\
\text { wrong attitudes. } \\
\text { * The excess of self-confidence } \\
\text { makes the subject difficult to } \\
\text { understand and can be seen as a } \\
\text { lack of acceptance against } \\
\text { losing. }\end{array}$ & $\begin{array}{l}\text { K1, K10 } \\
\text { K4 } \\
\text { K9 } \\
\text { K15 } \\
\text { K20 } \\
\text { K3 }\end{array}$ & 7 & 35 & $\begin{array}{l}\text { Other } \\
\text { * I can't socialize. Ö3 } \\
\text { Ö30 }\end{array}$ & 2 & 3,63 \\
\hline Total & & 20 & 100 & & 55 & 100 \\
\hline
\end{tabular}

When the findings in Table 4 are examined, it is seen that $50 \%$ of the teachers state working with special talented students is exhausting, and $15 \%$ of them feel obliged to come up with something new. While two of the teachers stated that there was no negative situation they encountered apart from the common answers, they both stated that they did not experience any negativity when they were together with the special talented students, but that they had difficulty in the education process due to the wrong attitudes of their parents. They describe being together with special talented students as wearisome, the omniscient attitude of special talented students and the feeling of constantly having to come up with something new as a negativity. On the other side, $34.54 \%$ of the students said that there was no negative side of studying with their special talented fellows. In addition, $16.36 \%$ of the students stated that they felt as if they were competing with their friends, $12.72 \%$ of them said that their friends had smug attitudes, there was a constant rush and they had difficulty in keeping up with the speed of this hustle. Two of the students see being together with special talented students as a negativity that prevents socialization. According to both teachers and students, backbreaking side of working with special talented students, difficulty in keeping up with their speeds, feeling inadequate and their all-know and smug attitudes are negative aspects of being together with special talented students. To give examples of expressions of teachers and students about the related question, teachers $\mathrm{K} 1$ and $\mathrm{K} 10$ stated that "There is no negative side of working with special talented students" and K4 talked about the parents and said, "I didn't experience it, but that parents made the process difficult for children with their wrong attitudes. Also, teachers K9, K15, K20 and K3 mentioned about the negative feeling of not being able to accept caused by the excess of selfconfidence as "Excess self-confidence makes it difficult to understand the subject and can 
be seen as being unable to accept against losing." On the other hand, students Ö3 and Ö30 stated that "I can't socialize", Ö1 and Ö3 said that "There is no negativity and Ö11 told that "I can't tolerate the smug attitudes of my friends."

\subsubsection{Opinions on Negative Behaviors of Special Talented Students in Classroom Environment}

In the study, the question "What are the negative behaviors of special talented students in the classroom environment?" was asked to the teachers and students in the Science and Art Center, and their answers are described in Table 5.

Table 5: Opinions on Negative Behaviors of

Special Talented Students in Classroom Environment

\begin{tabular}{|c|c|c|c|c|c|c|c|}
\hline Items & Teachers & $\mathbf{n}$ & $\%$ & \multicolumn{2}{|l|}{ Students } & $\mathbf{n}$ & $\%$ \\
\hline $\begin{array}{l}\text { a) Willingness to talk } \\
\text { about extracurricular } \\
\text { topics. }\end{array}$ & $\begin{array}{l}\text { K2, K10, K11, } \\
\text { K12, K17, K18, } \\
\text { K19 }\end{array}$ & 7 & 35 & \multicolumn{2}{|c|}{$\begin{array}{l}\text { Ö8, Ö15, Ö19, Ö21, Ö26, Ö27, } \\
\text { Ö28, Ö29, Ö31, Ö33, Ö50, Ö51, } \\
\text { Ö52, Ö53 }\end{array}$} & 14 & 24,45 \\
\hline $\begin{array}{l}\text { b) Restless and dynamic } \\
\text { behavior. }\end{array}$ & K9, K16 & 2 & 10 & \multicolumn{2}{|c|}{$\begin{array}{l}\text { Ö9, Ö20, Ö22, Ö24, Ö25, Ö39, } \\
\text { Ö40, Ö41, Ö47, Ö49, Ö54 }\end{array}$} & 11 & 20 \\
\hline $\begin{array}{l}\text { c) Constantly criticizing } \\
\text { friends and teachers. }\end{array}$ & K5 & 1 & 5 & & & & \\
\hline $\begin{array}{l}\text { d) Exhibiting aggressive } \\
\text { behaviors. }\end{array}$ & K4 & 1 & 5 & \multicolumn{2}{|c|}{ Ö12, Ö13, Ö32, Ö34, Ö36, Ö37 } & 6 & 10,90 \\
\hline $\begin{array}{l}\text { e) Reluctantly } \\
\text { participating in activities. }\end{array}$ & $\begin{array}{l}\text { K3, K6, K8, } \\
\text { K13, K15 }\end{array}$ & 5 & 25 & \multicolumn{2}{|l|}{ Ö7, Ö10, Ö11, Ö17, Ö55 } & 5 & 9,09 \\
\hline $\begin{array}{l}\text { f) Inability to tolerate } \\
\text { repetition of stories. }\end{array}$ & & & & \multicolumn{2}{|l|}{ Ö18, Ö23, Ö42, Ö46 } & 4 & 7,27 \\
\hline g) None. & K1 & 1 & 5 & \multicolumn{2}{|c|}{$\begin{array}{l}\text { Ö1, Ö2, Ö4, Ö5, Ö6, Ö14, Ö16, } \\
\text { Ö35, Ö38, Ö43, Ö44, Ö45 }\end{array}$} & 12 & 21,81 \\
\hline $\begin{array}{l}\text { h) Other. } \\
\text { * Insist on his/her answer } \\
\text { to the teacher's response. } \\
\text { *All. } \\
\text { * Overconfidence causing } \\
\text { mistakes. }\end{array}$ & $\begin{array}{l}\text { K7 } \\
\text { K14 } \\
\text { K20 }\end{array}$ & 3 & 15 & $\begin{array}{l}\text { Other } \\
* \text { Shouting. } \\
* \text { Getting spoiled. } \\
{ }^{*} \text { Exhibiting know-it-all } \\
\text { behaviours. } \\
{ }^{*} \text { Distracting by } \\
\text { speaking without } \\
\text { permission. }\end{array}$ & $\begin{array}{l}\text { Ö30 } \\
\text { Ö48 }\end{array}$ & 3 & 5,45 \\
\hline Total & & 20 & 100 & & & 55 & 100 \\
\hline
\end{tabular}

When the findings in Table 5 are examined, 35\% of the teachers stated the desire of special students' to talk about extracurricular issues as negativeness. While $25 \%$ of the teachers describe their reluctant participation in classroom activities as a negative behavior, $10 \%$ of the teachers express being restless and active in the classroom as a negative behavior. Some of the teachers, on the other hand, state students' constantly criticizing discourses, being in aggressive attitudes, insisting on their answers and making mistakes due to their excessive self-confidence as negative behaviors. When the expressions of the students are examined, $24.45 \%$ of them see the willingness of their special talented friends to talk 
about extracurricular issues as a negativity, while $21.81 \%$ say that they do not act negatively. On the other hand, $20 \%$ of the students state active and restless behaviors in the classroom as a negativity. Other students describe the negative behavior of special talented students as being aggressive, spoiled and know-it-all behaviours in the classroom, causing distraction by speaking without permission, and being intolerant of repeating what is told. To give an example of what the participants said, K5 stated negative behaviors as "constantly criticizing friends and teachers in class", K7 "insistence in answering the teacher's answer"; Ö8 and Ö15 "the desire to talk about extracurricular subjects"; Ö30, on the other hand, describes the behaviors of "showing spoiled and knowing attitudes" as negativity.

\subsection{Suggestions Related to Special Talented Students}

To students and teachers at the Science and Art Center; it was asked and evaluated what kind of suggestions they had regarding what can be done to reveal the positive aspects of special talented students more and to eliminate their negative aspects.

\subsubsection{Suggestions for Revealing More Positive Sides of Special Talented Students}

Suggestions of students and teachers in the Science and Art Center for revealing more positive aspects of special talented students were examined by asking the question "What are your suggestions for revealing more positive aspects special talented students?" The data obtained within the scope of this question are depicted in Table 6.

Table 6: Suggestions for Revealing More Positive Sides of Special Talented Students

\begin{tabular}{|c|c|c|c|c|c|c|}
\hline Items & Teachers & $\mathbf{n}$ & $\%$ & Students & $\mathbf{n}$ & $\%$ \\
\hline $\begin{array}{l}\text { a) Opening new courses, workshops, } \\
\text { predominance of art education, suitable } \\
\text { educational environments. }\end{array}$ & $\begin{array}{l}\text { K2, K10, K18, } \\
\text { K19, K20 }\end{array}$ & 5 & 25 & $\begin{array}{l}\text { Ö1, Ö3, Ö4, Ö11, } \\
\text { Ö13, Ö25, Ö36, } \\
\text { Ö42, Ö43, Ö47, } \\
\text { Ö51 }\end{array}$ & 11 & 20 \\
\hline b) Concentration training should be given. & & & & $\begin{array}{l}\text { Ö5, Ö18, Ö38, Ö39, } \\
\text { Ö40, }\end{array}$ & 4 & 7,27 \\
\hline $\begin{array}{l}\text { c) Diagnostic exams should be more } \\
\text { decisive. }\end{array}$ & & & & Ö7, Ö20 & 2 & 3,63 \\
\hline d) Training should be done on weekends. & K8 & 1 & 5 & Ö8 & 1 & 1,8 \\
\hline $\begin{array}{l}\text { e) Special talented students should be } \\
\text { given training on their behavior. }\end{array}$ & & & & $\begin{array}{l}\text { Ö9, Ö10, Ö22, Ö23, } \\
\text { Ö30, Ö39 }\end{array}$ & 5 & 9,09 \\
\hline $\begin{array}{l}\text { f) Course selection should be left to } \\
\text { students and assigned specific research } \\
\text { assignments. }\end{array}$ & K7 & 1 & 5 & Ö6, Ö11, Ö48 & 2 & 3,63 \\
\hline $\begin{array}{l}\text { g) The number of students in elective } \\
\text { courses should be reduced. }\end{array}$ & & & & Ö11, Ö16 & 2 & 3,63 \\
\hline $\begin{array}{l}\text { h) Studies should be carried out according } \\
\text { to the future plans of the students. }\end{array}$ & & & & $\begin{array}{l}\text { Ö12, Ö15, Ö26, } \\
\text { Ö32, Ö35, Ö41, } \\
\text { Ö49, Ö55 }\end{array}$ & 8 & 14,5 \\
\hline $\begin{array}{l}\text { 1) Visual media publication branches such } \\
\text { as newspapers and magazines should be } \\
\text { established. }\end{array}$ & & & & Ö14 & 1 & 1,8 \\
\hline
\end{tabular}




\begin{tabular}{|c|c|c|c|c|c|c|}
\hline $\begin{array}{l}\text { j) Activities should be implemented in } \\
\text { different ways and allow students to } \\
\text { explore. }\end{array}$ & $\begin{array}{l}\text { K1, K3, K4, } \\
\text { K9, K12 }\end{array}$ & 5 & 25 & $\begin{array}{l}\text { Ö17, Ö24, Ö28, } \\
\text { Ö31, Ö33, Ö34, } \\
\text { Ö37, Ö53 }\end{array}$ & 8 & 14,5 \\
\hline k) Building facilities should be improved. & K11 & 1 & 5 & $\begin{array}{l}\text { Ö27, Ö37, Ö38, } \\
\text { Ö45, Ö46, Ö51 }\end{array}$ & 6 & 10,9 \\
\hline 1) None. & K15, K16 & 2 & 10 & $\begin{array}{l}\text { Ö2, Ö19, Ö29, Ö44, } \\
\text { Ö52 }\end{array}$ & 5 & 9,09 \\
\hline $\begin{array}{l}\text { m) Teachers should be given training for } \\
\text { special talented students, family education, } \\
\text { and values education. }\end{array}$ & $\begin{array}{l}\text { K5, K6, K13, } \\
\text { K14, K17 }\end{array}$ & 6 & 30 & & & \\
\hline Total & & 20 & 100 & & 55 & 100 \\
\hline
\end{tabular}

According to the findings in Table 6, teachers and students made various suggestions and these suggestions were gathered under common headings. 30\% of the teachers said that the trainings for the education of special talented students should be increased and that the families should receive training on this subject. $25 \%$ of the teachers suggested that appropriate educational environments should be increased, and the number of workshops should be increased by focusing on arts education. They also said that the activities to be implemented should have different and rich content and enable students to discover themselves. Students also offered different and numerous suggestions. 20\% of them said that new courses should be added to their curriculum and new classrooms should be built. $14.5 \%$ of them said that trainings should be given in accordance with their future plans, the activities in the lessons should be different and they should be in a way to reveal their talents. The teachers gave suggestion as K1 "There should be subjects based on their interest in the activities and they should be directed to activities that will attract their attention", K3 "Different techniques should be used and constant occupations", K4 "By organizing activities that will allow them to discover their interests and special talents, group work should be focused on eliminating competition and strengthening the values of solidarity and cooperation.", $\mathrm{K} 5$ "Teachers should be subject to training for special talented students", K6 "Communication channels with families should be opened and family training should be provided", K7 "Students should be made aware of their abilities by giving them project assignments such as special research or examination", K8 "The activities to be carried out should be at more convenient times for the students by providing concrete responses to the activities carried out", K9 "At the end of the year, students should be able to discover their talents by repeating the interest and ability tests", K10 "Art education should be given more emphasis", K11 "Buildings suitable for their education need to be arranged", K12 "Different activities need to be done", K13 “Teachers need to be supported by postgraduate education", K14 "Emotional intelligence development activities should be carried out with emphasis on values education", K17 "Family education should be given", K19 "More different and free workshops should be opened within the institution". On the other hand, students gave suggestions as Ö5 and Ö18 "Concentration training should be given", Ö17 and Ö24 "Activities should be implemented with different methods and studies should be carried out that will allow students to discover themselves and their abilities", Ö14 "Visual 
media publication branches such as newspapers and magazines should be established by science and art centers."

\subsection{Suggestions for Removing the Negative Sides of Special Talented Student}

Suggestions of students and teachers in the Science and Art Center for removing the negative sides of special talented students were examined by asking the question "What are your suggestions for eliminating the negative aspects of special talented students?" The data obtained within the scope of this question are depicted in Table 7.

Table 7: Suggestions for Eliminating the Negative Sides of Special Talented Students

\begin{tabular}{|c|c|c|c|c|c|c|}
\hline Items & Teachers & $\mathbf{n}$ & $\%$ & Students & $\mathbf{n}$ & $\%$ \\
\hline $\begin{array}{l}\text { a) Presence of visuals that will raise } \\
\text { awareness in the building, physical } \\
\text { arrangement of buildings. }\end{array}$ & K6 & 1 & 5 & Ö3, Ö14, Ö24, Ö30, Ö36 & 5 & 9,09 \\
\hline $\begin{array}{l}\text { b) Pay attention to their classroom } \\
\text { behavior. }\end{array}$ & & & & $\begin{array}{l}\text { Ö6, Ö20, Ö21, Ö22, Ö25, } \\
\text { Ö27, Ö28, Ö40, Ö48, Ö49, } \\
\text { Ö53 }\end{array}$ & 11 & 20 \\
\hline $\begin{array}{l}\text { c) More attention should be paid to } \\
\text { students and activities related to } \\
\text { their areas of interest should be } \\
\text { increased. }\end{array}$ & $\begin{array}{l}\mathrm{K} 4, \mathrm{~K} 8, \mathrm{~K} 9, \\
\mathrm{~K} 18, \mathrm{~K} 20\end{array}$ & 5 & 25 & Ö7, Ö10, Ö16, Ö23 & 4 & 7,27 \\
\hline $\begin{array}{l}\text { d) Training should be given on } \\
\text { student behavior. }\end{array}$ & $\begin{array}{l}\text { K5, K11, } \\
\text { K14 }\end{array}$ & 3 & 15 & $\begin{array}{l}\text { Ö12, Ö15, Ö18, Ö26, Ö31, } \\
\text { Ö32, Ö33, Ö34, Ö43, Ö54, } \\
\text { Ö55 }\end{array}$ & 11 & 20 \\
\hline $\begin{array}{l}\text { e) Students should not be put in a } \\
\text { competitive environment. }\end{array}$ & & & & Ö13, Ö15, Ö19 & 3 & 5,45 \\
\hline $\begin{array}{l}\text { f) Arrangements should be made in } \\
\text { event times and practices. }\end{array}$ & K3, K15 & 2 & 10 & Ö18, Ö35, Ö46 & 3 & 5,45 \\
\hline g) None. & K16 & 1 & 5 & $\begin{array}{l}\text { Ö1, Ö2, Ö4, Ö8, Ö9, Ö11, } \\
\text { Ö29, Ö37, Ö38, Ö39, Ö41, } \\
\text { Ö42, Ö44, Ö45, Ö47, Ö50, } \\
\text { Ö51, Ö52 }\end{array}$ & 18 & 32,7 \\
\hline $\begin{array}{l}\text { h) Cooperation with the family and } \\
\text { family education. }\end{array}$ & $\begin{array}{l}\text { K1, K7, } \\
\text { K10, K13, } \\
\text { K19 }\end{array}$ & 5 & 25 & & & \\
\hline $\begin{array}{l}\text { 1) Values education should be given, } \\
\text { reading books should be } \\
\text { encouraged. }\end{array}$ & $\begin{array}{l}\text { K2, K12, } \\
\text { K17 }\end{array}$ & 3 & 15 & & & \\
\hline Total & & 20 & 100 & & 55 & 100 \\
\hline
\end{tabular}

When the findings in Table 7 are examined, it is seen that the teachers made common suggestions that students should be taken care of in order to eliminate the negative behaviours exhibited and that they should receive training for students by strengthening the communication with their families. In addition, K1 suggested that "The continuity of the course should be ensured and cooperation with the family should be made", K3 "Event times should be regulated by organizing activities that will enable them to spend their time to the fullest", K4 "By paying more attention to the students, the focus of 
attention should be determined and activities should be carried out in this direction", K5 "Behavioural training should be given", K6 "Physical sites that will discharge their energies should be arranged", K7 "Be flexible and help families understand them by providing trainings", K8 "Activities in the area of interest should be more weighted", K13 "Families and students should be supported by providing cooperation with the family", K14 "Behavioural training should be conducted to develop disciplined working, knowledge acquisition and sharing skills".

While the majority of the students did not make any suggestions to eliminate the negative behaviors of special talented students, some students stated that special talented students should pay attention to their in-class behaviors and be trained in behaviors. Increasing the equipment inside the building and paying more attention to the students are among the other suggestions. The students also suggested that special talented students should not be put into the competition environment and that the negative aspects of special talented students should be regulated in activity times and practices.

\section{Discussion and Conclusion}

According to the research, students and teachers in the Science and Art Center perceive the concept of special talented students as individuals who offer creative solutions to problems and who have a quick grasp. These results are similar to the results of Sternberg's (1999) stating that giftedness arises from the balance between analytical, practical and creative abilities, and Ayaydın and Ün's (2018) study that BILLSEM teachers perceive special talented students as individuals who understand quickly.

The majority of the teachers and students, whose opinions were taken about the contribution of the education program implemented in BILLSEM to the students, think that the program contributes to increase the knowledge of the students and to enable them to look at the students from different perspectives. This shows that receiving education at BILSEM makes positive contributions to students. These results show that in the study of Epçan and Oral (2019), students mostly; problem solving skills, research and questioning skills, the opportunity to discover talents and the opportunity to develop talents are similar to the statements that the institution makes significant contributions to them. In addition, Atli and Balay (2016) stated in their study that students are happy to study at BİLSEM. Similarly, Kazu and Şenol (2012) found in their research that Science and Art Centers help students realize their individual abilities. When the opinions of the students about the negative effects of studying with their special talented friends are examined, it is understood that the majority of the students have the opinion that there is no negative side of being educated with their special talented friends. It is seen that very few of the students consider having to create something new as a negative side of being educated with their special talented friends. The majority of the teachers, on the other hand, stated that they were very worn out while working with special talented students and that their work required a lot of effort. The findings are supported by the findings of previous studies. Ayaydın and Ün (2018) stated in their research that it was 
concluded that BİLSEM teachers felt inadequate to work with special talented students, had to produce new things and had some negative effects such as being tiring. In this context, Sak (2010) researched that the teachers of special talented students should have expertise in their fields; Summak and Çelik-Şahin (2014), on the other hand, emphasized that teachers should respect creativity and imagination, care about student needs, and be open to development by continuing their education. This situation shows that teachers of special talented students should improve themselves in many ways.

In the study, when students and teachers were asked about the negative behaviours of special talented students in the classroom environment, it was seen that the desire of the students in both groups to talk outside the classroom was considered as the negative behaviour of the special talented students. As an example of the negative behaviors of special talented students in the classroom environment, Wagale (2001) found that special talented and success-oriented children sometimes cause problems for their teachers in the classroom environment because of their stubborn and dominant behaviours. In addition, Mares (1991) states in his research that special talented people generally exhibit advanced learning behaviours due to their intellectual risk-taking tendency, they break the rules in an unusual and unexpected way, and this situation can be perceived by teachers as the behaviour of the special talented to cause confusion in the classroom environment. In the study of Balay and Sağlam (2008), teachers state that they frequently encounter negative student behaviours in the classroom environment. Sezer (2015), on the other hand, states the views of teachers about the negative behaviours of special talented students as constantly demanding the right to speak, exhibiting meaningless restlessness and activity, criticizing the answers of their friends, verbally teasing their friends, being stubborn with the teacher, speaking without speaking and exhibiting aggressive behaviours.

When the suggestions given by the students to reveal the positive behaviours of the special talented students more are examined, it is seen that the opening of new courses and workshops is the most recommended topic. Ayaydın and Ün (2008) stated that most of the teachers in their studies stated that there are deficiencies in the curricula applied in Science and Art Centers, that they continue to work to improve it, that individual curricula should be prepared together with academic support, and that different practices are needed. Kaya (2013) similarly stated that the education of special talented students should be different in line with their needs.

The suggestions given by the students to eliminate the negative behaviors of the special talented students include paying attention to the behaviors of the special talented students in the classroom, providing training on behaviors, increasing the equipment inside the building, paying more attention to the students, not putting the them into the competition environment, and making arrangements in the times of activities and practices. In the study of Çankaya (2011) in terms of eliminating the negativities, cooperation with the family, individual guidance, participation in social activities, making codecisions, gaining responsibility, supporting the development of students' special abilities, and preventing negative behaviors in the classroom are seen as 
permanent solutions. In addition to this, Sezer (2015) states in his study that teachers who take part in the education of special talented students should be better equipped about special education and closely monitor the practices in different countries. He also states that teachers should be given in-service training on providing necessary materials to schools where special talented students are educated, enriching classroom learning environments, and preparing individualized educational activities. Furthermore, he emphasizes that teachers should be informed that the negative behaviors exhibited by special talented children in the classroom environment depend on their developmental characteristics and that special training and guidance seminars should be given to teachers about the management of these behaviors.

Students and teachers have generally defined the concept of giftedness as individuals who have a quick grasp and who offer creative solutions to problems. The education programs implemented to those students provide an increase in their knowledge. It makes easier for teachers to look from different angles. Special talented students say that there is no downside to being together. Teachers, on the other hand, find it tiring to work with special talented students. Students state the negative behaviors exhibited in the classroom environment as the desire to speak out of class and restless, active behaviors. Teachers, on the other hand, see negative behaviors in the classroom as a desire to speak out of class and unwillingness to participate in activities. Teachers demand more activities and workshops to discover talents. Students want new workshops and studies planning for the future. In order to eliminate negativities, teachers recommend approaching students with interest and guidance work for families. Finally, students suggest that classroom behavior should be emphasized.

\section{Recommendations}

Some suggestions can be given in the light of the findings of this research. First of all, new courses and workshops for special talented students can be opened in Science and Art Centers to increase their potentials. Second, the curriculum applied in Science and Art Centers can be enriched. Thirdly, psychological and behavioural support can be provided for those students. Finally, the number of the equipment inside the building can be increased.

\section{Conflict of Interests Statement}

The authors declare that there is no conflict of interest.

\section{About the Authors}

Cavide Demirci is a Professor at Osmangazi Univesity of Faculty of Education, Turkey. Please visit https://akademik.yok.gov.tr/AkademikArama/view/viewAuthor.jsp for more information.

Sedef Çelik is an English teacher at Ministry of Education in Turkey. She is also currently a MA student at Eskişehir Osmangazi University, Turkey. 
Sündüz Özer is a Special Education teacher at Ministry of Education in Turkey. She is also currently a MA student at Eskişehir Osmangazi University, Turkey.

\section{References}

Akbüber, B. A., Erdik, E., Güney, H., Çimşitoğlu, G. G., Akbüber, C. (2019). Bilim ve sanat merkezleri'nde özel yetenekli öğrencilerin sorunlarının değerlendirilmesinde bir yöntem önerisi "özel yetenekli çocuk çalıştayı". Özel Yetenekli Çocuk Çalıştayı. Üstün Zekalılar Ĕ̆itimi ve Yaratıcllık Dergisi, 6(1), 22-39.

Atlı, H. \& Balay, R. (2016). Bilim ve sanat merkezindeki üstün yetenekliler eğitiminin sürdürülebilirliğine ilişkin öğrenci düşünceleri. Journal of Kırşehir Education Faculty, 17(2).

Ayaydın, Y. \& Ün, D. (2018) Bilim ve sanat merkezi öğretmenlerinin BİLSEM ve üstün yetenekli öğrencilerin eğitimine yönelik görüşleri. Amasya Üniversitesi Ĕ̆itim Fakültesi Dergisi 7(1), 121-155.

Bakioğlu, A. \& Levent, F. (2013). Üstün yeteneklilerin eğitiminde Türkiye için öneriler. Üstün Yetenekliler Ĕ̆gitimi Araştırmaları Dergisi, 1(1), 31-44.

Balay, R., \& Sağlam, M. (2008). Sınıf içi olumsuz davranışlara ilişkin öğretmen görüşleri. Yüzüncü Yıl Üniversitesi Ĕ̆itim Fakültesi Dergisi, 5(2), 1-24.

Bıçakçı, M. Y., Er, S., Aral, N. (2017). Annelerin çocuklarına etkileşimli kitap okuma sürecine ilişkin görüşleri. Ĕ̆itim ve Bilim Dergisi, 42 (191), 53-68.

Büyüköztürk, Ş., Kılıç Çakmak, E., Akgün, Ö. E., Karadeniz, Ş. \& Demirel, F. (2014). Bilimsel araştırma yöntemleri. Ankara: PegemA Yayıncılık.

Cevher Kılıç, V. (2015). Türkiye' de üstün ve üstün yetenekli çocuklara yönelik bir eğitim politikası oluşturulamaması sorunu üzerine bir değerlendirme. 21. Yüzyılda Ĕ̆itim ve Toplum Dergisi, 4(12), 145-154.

Çankaya, İ. (2011). Sınıf öğretmenlerinin karşılaştıkları istenmeyen öğrenci davranışları ve bu davranışlarla başa çıkma yolları. Turkish Studies, 6(2), 307-316.

Dereli, F. (2019). Okul öncesi dönemdeki üstün yetenekli çocukların aday gösterilmelerine yönelik geliştirilen eğitim programının etkililiği (Yayınlanmamış Doktora Tezi). Hacettepe üniversitesi Ĕ̆itim Bilimleri Enstitüsü, Ankara.

Dilekli, Y. \& Tezci, E. (2019). Üstün yetenekli öğrencilerin öğrenme strateji tercihleri. Abant İzzet Baysal Üniversitesi Eğitim Fakültesi Dergisi, 19(1), 184-193.

Epçaçan, U. \& Oral B. (2019) Özel yetenekli öğrencilerin BİLSEM' deki öğretim uygulamalarına ilişkin görüşleri. Siirt Üniversitesi Sosyal Bilimler Enstitüsü Dergisi, 7(13), 139-166.

Erdoğan, S. C. \& Güçyeter, Ş. (2019). Öğretmen adaylarının üstün zekâ ve üstün yetenek metaforları. Elementary Education Online, 18(3).

Kaya, N. G. (2013). Üstün yetenekli öğrencilerin eğitimi ve BİLSEM' ler. Erzincan Üniversitesi Ĕ̆itim Fakültesi Dergisi, 15(1), 115-122. 
Kayişdağ, E. \& Melekoğlu, M. A. (2019). Bilim ve sanat merkezlerinin eğitim programlarının öğrenci görüşlerine dayalı olarak değerlendirilmesi. Eskişehir Osmangazi Üniversitesi Sosyal Bilimler Dergisi, 20, 175-202.

Kazu, Y. \& Şenol, C. (2012). Üstün yetenekliler eğitim programlarına ilişkin öğretmen görüşleri (BİLSEM Örneği). e-international Journal of Educational Research, 3(2), 1335.

Koçak, R. \& İçmenoğlu, E. (2016). Üstün yetenekli öğrencilerin duygusal zekâ ve yaratıcılık düzeylerinin yaşam doyumlarını yordayıcı rolü. Türk Psikolojik Danışma ve Rehberlik Dergisi, 4(37).

Levent, F. (2012). Bilsem öğretmenlerine göre üstün yetenekli öğrencilerin sosyo-duygusal özellikleri. Namık Kemal Üniversitesi Sağlık Hizmetleri Meslek Yüksekokulu “Geleceğin Mimarları Üstün Yetenekliler Sempozyumu. 29-34.

Mares, L. (1991). Young gifted children. Australia: Hawker-Brownlow Education Press.

McCarty, F., Abbott-Shim, M. \& Lambert, R. (2001). The relationship between teacher beliefs and practices, and head start classroom quality. Early Education $\mathcal{E}$ Development, 12, 225-238.

MEB, (2016). Bilim sanat merkezleri yönergesi. Tebliğler Dergisi, 79(2710), 449-473, http://orgm.meb.gov.tr/meb iys dosyalar/2017 01/02031535 tebligler dergisi.pd $\underline{f}$ adresinden elde edildi.

Özarslan, M. (2019). Üstün zekâlı ve yetenekli öğrenciler ile normal gelişim gösteren öğrencilerin bitkilere yönelik tutumlarının karşılaştırılması. Elementary Education Online, 18(4).

Sak, U. (2010). Üstün zekâlılar (üstünlükleri tanılanmaları ve eğitimleri). Ankara: Maya Akademi.

Seeman, H. (2010). Preventing disruptive behavior in colleges: A campus and classroom management handbook for higher education. UK: Rowman \& Littlefield Education Press.

Sezer Ş. (2015). Üstün yeteneklilerin sınıf içindeki olumsuz davranışları ve yönetilmesine ilişkin öğretmen görüşleri. Uluslararası Türk Ĕ̆itim Bilimleri Dergisi, (4), 317-333.

Sternberg, R. J. (1999). The theory of successful intelligence. Review of General Psychology, 3, 292-316.

Summak, S. M. \& Çelik, Ş. Ç. (2014). Bilim ve Sanat Merkezlerinde yönetici, öğretmen yeterlilikleri ve öğretimsel hedefler için standartların belirlenmesi. Üstün Yeteneklileri Ĕ̆itimi Araştırmaları Dergisi, 2(2), 86-104.

Tortop, H. S. \& Ersoy, B. (2015). Üstün Yetenekliler Üniversite Köprüsü Eğitim Programı'na (ÜYÜKEP) katılan üstün yetenekli öğrencilerin sınıf öğretmenlerinin ÜYÜKEP hakkındaki görüşleri. Üstün Zekâlılar Eğitimi ve Yaratıcılık Dergisi, 2(1), 17-24.

Wagale, E. (2001). Enneagram yöntemiyle çocuk yetiştirmek. (Çev: Günseli Aksoy). İstanbul: Rota Yayınları.

Yıldırım, A. \& Şimşek, H. (2011). Sosyal bilimlerde nitel araştırma yöntemleri. Ankara: Seçkin Yayıncilik. 
Yıldırım, A. \& Şimşek, H. (2018). Sosyal bilimlerde nitel araştırma yöntemleri. Ankara: Seçkin Yayıncilik.

Yumuş, A. \& Toptaş, V. (2011). Bilim ve Sanat Merkezlerinin amacına uygun işleyişinin değerlendirilmesi. Mersin Üniversitesi Ĕ̆itim Fakültesi Dergisi, 7(2), 80-88.

Creative Commons licensing terms

Authors will retain the copyright of their published articles agreeing that a Creative Commons Attribution 4.0 International License (CC BY 4.0) terms will be applied to their work. Under the terms of this license, no permission is required from the author(s) or publisher for members of the community to copy, distribute, transmit or adapt the article content, providing a proper, prominent and unambiguous attribution to the authors in a manner that makes clear that the materials are being reused under permission of a Creative Commons License. Views, opinions and conclusions expressed in this research article are views, opinions and conclusions of the author(s). Open Access Publishing Group and European Journal of Special Education Research shall not be responsible or answerable for any loss, damage or liability caused in relation to/arising out of conflict of interests, copyright violations and inappropriate or inaccurate use of any kind content related or integrated on the research work. All the published works are meeting the Open Access Publishing requirements and can be freely accessed, shared, modified, distributed and used in educational, commercial and non-commercial purposes under a Creative Commons Attribution 4.0 International License (CC BY 4.0). 